\title{
Pengadilan yang Fair: Kecenderungan Pelanggaran Kode Etik dan Pedoman Perilaku Oleh Hakim
}

\author{
Suparman Marzuki \\ Fakultas Hukum Universitas Islam Indonesia \\ Jl. Tamansiswa No. 158 Yogyakarta \\ mzpushamuii@yahoo.com
}

\begin{abstract}
Fair trials are universal principles included in various international human rights instruments, procedural law and professional codes of conduct that guide judges in analyzing, hearing and deciding cases. Identifying these isntruments enables us to assess the presence or absence of a fair trial. On this basis, the researcher formulates the research problems in the study as follows: first, what is the tendency of violation of the Code and the Judicial Code of Conduct (KE PPH)? Second, what is the tendency of the recommended sanction and sentence for the period of 9 (nine) years of KY (2005-2014)? This research is classified as non doctrinal legal research with socio-legal approach. The study concluded that: first, for the first five-year period, there are no significant increasing trend of case reports, while during the second five years there was a significant raise of case report. Meanwhile, the most region with most case reports is Jakarta Special Region. The most common type of violations of KE PPH is the unprofessional, undisciplined, unfair and dishonest behavior of the judge. Second, as with types of sanctions the moderate sanctions and medium sanctions are highly dominant. Meanwhile severe sanctions in the form of dishonorable discharge, dismissal with pension rights and unofficial sanction for 1-2 years is likely to increase from year to year.
\end{abstract}

Keywords : Fair trial, code of conduct, trends, abuse.

\begin{abstract}
Abstrak
Pengadilan yang fair adalah prinsip universal yang termuat dalam pelbagai instrumen HAM internasional, hukum acara, dan kode etik profesi yang menjadi pedoman hakim dalam memeriksa, mengadili dan memutus perkara. Untuk menilai ada tidaknya pengadilan yang fair dapat diidentifikasi melalui instrumen-instrumen tersebut. Permasalahan dalam penelitian ini: pertama, kecenderungan pelanggaran Kode Etik dan Pedoman Perilaku Hakim (KE PPH). Kedua, kecenderungan sanksi yang direkomendasikan dan dijatuhkan selama 9 (sembilan) tahun KY (2005-2014). Penelitian ini tergolong penelitian hukum nondoktrinal dengan pendekatan sosiolegal. Hasil penelitian menyimpulkan: pertama, pada periode lima tahun pertama, tidak terdapat kecenderungan peningkatan laporan yang berarti, sementara pada lima tahun kedua terjadi peningkatan signifikan. Begitu pula dengan wilayah pemasok laporan; DKI Jakarta adalah wilayah pengadilan yang paling tinggi pemasok laporan. Jenis pelanggaran KE PPH cenderung didominasi oleh prilaku hakim tidak profesional, tidak berdisiplin tinggi, tidak adil dan tidak jujur. Kedua, untuk jenis sanksi, dominan sanksi ringan dan sanksi sedang. Sanksi berat berupa pemberhentian tidak hormat, pemberhentian dengan hak pensiun dan non palu selama 1-2 tahun cenderung meningkat dari tahun ke tahun.
\end{abstract}

Kata kunci: Pengadilan yang adil, kode etik, kecenderungan, pelanggaran. 


\section{Pendahuluan}

Pengadilan yang fair atau pengadilan yang adil adalah prinsip universal yang harus dijalankan oleh pengadilan untuk melindungi hak asasi manusia dan hak-hak konstitusional warganegara dari kemungkinan pelanggaran oleh aparat penegak hukum, khususnya saat seseorang berurusan dengan hukum di pengadilan.

Standar yang digunakan untuk menilai apakah suatu proses persidangan itu adil banyak jumlahnya, kompleks dan terus berubah. Standar tersebut bisa merupakan kewajiban-kewajiban yang mengikat yang terdapat dalam traktattraktatHAM dimana suatu negara telah menjadi pihak, tetapi standar itu juga bisa ditemukan dalam dokumen-dokumen dan kebiasaan internasional.

Dokumen-dokumen yang dapat digunakan untuk mengetahui standar peradilan yang adil ialah Basic principles for treatment of prisoners, ${ }^{1}$ UN standard Minimum Rules for the Administration of Juvenile Justice, ${ }^{2}$ Code of Conduct for Law Enforcement Officials ${ }^{3}$, Guidelines on the Role of Prosecutors, ${ }^{4}$ Body of Principles for the Protection of All Person under any form of Detention or Imprrisonmen ${ }^{5}$, Basic Principles on the Role of Lawyers, ${ }^{6 P r i n c i p l e s}$ on the Effective Prevention and Investigation of extralegal 7 , Arbitrary and Summary Executions ${ }^{8}$, Basic Principles on the Use of force and firearms by Law enforcement Officialls ${ }^{9}$, UN Rules for The Protections of Juveniles deprived of their liberty ${ }^{10}$, Standard Minimum Rules for the Treatement of Prisoners, ${ }^{11}$ The Bangalore Principles of Judicial Conduct, 12 dll.

\footnotetext{
${ }^{1}$ General Assembly resolution 45/111 of 14 December 1990

${ }^{2}$ General Assembly resolution 45/113 of 14 December 1990

${ }^{3}$ General Assembly resolution 34/169 of 17 December 1979

4 The Eighth United Nations Congress on the Prevention of Crime and the Treatment of Offenders, Havana,Cuba, 27 August to 7 September 1990

${ }^{5}$ General Assembly Resolution 43/173 (9 December 1988)

${ }^{6}$ the Eighth United Nations Congress on the Prevention of Crime and the Treatment of Offenders, Havana,Cuba27 August to 7 September 1990.

${ }^{7}$ United Nation Document. E/ST/CSDHA/.12 (1991).

${ }^{8}$ Recommended by Economic and Social Council Resolution 1989/65 of 24 May 1989

${ }^{9}$ United Nations Congress on the Prevention of Crime and the Treatment of Offenders, Havana, Cuba, 27 August to 7 September 1990

${ }^{10}$ General Assembly Resolution 45/113 of 14 December 1990

11 The First United Nations Congress on the Prevention of Crime and the Treatment of Offenders, held at Geneva in 1955, and approved by the Economic and Social Council by its resolutions 663 C (XXIV) of 31 July 1957 and 2076 (LXII) of 13 May 1977

12 The Bangalore Draft Code of Judicial Conduct 2001 adopted by the Judicial Group on Strengthening Judicial Integrity, as revised at the Round Table Meeting of Chief Justices held at the Peace Palace, The Hague, November 25-26, 2002.
} 
Deklarasi Universal Hak Asasi Manusia (DUHAM PBB) Pasal 10 menyebutkan bahwa "setiap orang, dalam persamaan yang penuh, berhak atas peradilan yang adil dan terbuka oleh pengadilan yang bebas dan tidak memihak, dalam menetapkan hak dan kewajiban-kewajibannya serta dalam setiap tuntutan pidana yang dijatuhkan kepadanya".

Dalam upaya melindungi hak-hak asasi manusia dari kemungkinan ancaman dan pelanggaran oleh penguasa, DUHAM PBB menekankan pentingnya pengadilan yang bebas dan merdeka. Lembaga pengadilan yang bebas itu diharapkan mampu melakukan pemeriksaan dan penilaian objektif atas kasuskasus sengketa hak yang dihadapkan kepadanya.

Pengadilan yang tidak memihak berkaitan erat dengan dijalankannya prinsip dan norma-norma hukum materil-substansif, hukum acara dan etika. Pelanggaran atas hal tersebut bukan hanya dikualifikasi sebagai pelanggaran prosedural dan etika, tetapi juga melawan hukum.

Hak atas pengadilan yang fair sebagai norma dalam hukum HAM internasional, dirancang untuk melindungi individu dari pembatasan yang tidak sah dan sewenang-wenang atau perampasan atas hak-hak dasar dan kebebasankebebasan lainnya. Dalam pemenuhan hak ini perlu diperhatikan bahwa sistem peradilan yang dimaksud tidak hanya melihat dan menilai, bagaimana proses pemeriksaan suatu kasus di muka persidangan saja, tetapi juga proses awal yang mendahului suatu peradilan atau pra persidangan dan juga paska persidangan.

Selain standar-standar internasional yang telah disebutkan di atas, suatu pengadilan dikualifikasi dijalankan fair atau tidak, tergantung juga pada apakah pengadilan (hakim) mematuhi hukum acara, dan Kode Etik Pedoman Perilaku Hakim (KE PPH) dalam memeriksa, mengadili dan memutus suatu perkara.

Dalam kaitan tersebut, Komisi Yudisial Republik Indonesia (KY RI) dibentuk oleh UUD 1945 untuk menjaga dan menegakkan kehormatan, keluhuran martabat dan perilaku hakim ${ }^{13}$, atau dengan kata lain memastikan pengadilan dijalankan dengan fair sehingga proses dan putusannya dinilai dan dirasakan pencari keadilan dan masyarakat umum sebagai proses dan putusan yang adil.

13 Pasal 24 B ayat (1) Undang-Undang Dasar Negara Republik Indonesia Tahun 1945. 
Selama sembilan tahun menjalankan wewenang dan tugasnya, KY telah banyak menerima laporan, temuan dan kesimpulan perihal perilaku hakim, proses persidangan dan putusannya yang memberi gambaran tertentu tentang kecenderungan-kecenderungan pelanggaran yang penting diketahui dan disebarluaskan kepada masyarakat untuk menjadi pelajaran bagi setiap orang tentang bagaimana kondisi pengadilan kita, dan bagaimana melakukan perbaikan-perbaikan.

Kecenderungan yang akan digambarkan dalam tulisan ini adalah kecenderungan angka-angka kuantitatif pelanggaran berdasarkan laporan dan proses penanganan laporan tersebut, yang juga memperlihatkan angka-angka kecenderungan lain, yang penting dan menarik untuk diketengahkan.

\section{Rumusan Masalah}

Terkait dengan latar belakang yang diuraikan dalam pendahuluan tersebut, maka masalah yang akan dijawab adalah bagaimana kecenderungan pelanggaran Kode Etik dan Pedoman Perilaku Hakim (KE PPH) serta kecenderungan sanksi yang direkomendasikan dan dijatuhkan selama 9 (sembilan) tahun KY?

\section{Tujuan Penelitian}

Penelitian ini bertujuan untuk dua hal: pertama, menemukan, mengungkap dan menjelaskan data-data kecenderungan pelanggaran KE PPH sebagai salah satu indikator ada tidaknya suatu proses dan putusan hakim yang fair. Kedua, mengungkap dan menjelaskan data-data kecenderungan sanksi yang direkomendasikan ke Mahkamah Agung. Dengan mengungkap dan menjelaskan hal-hal tersebut hakim (pengadilan), pencari keadilan, dan masyarakat umum bisa mengambil pelajaran untuk membenahi pengadilan. Bagi dunia akademik, temuan dalam penelitian ini berguna bagi upaya mengembangkan kajian-kajian akademis tentang pengadilan dan hakim Indonesia. 


\section{Metode Penelitian}

Penelitian ini tergolong penelitian hukum nondoktrinal dengan pendekatan sosiolegal. Subjek penelitian adalah prilaku hakim, baik perilaku personal maupun profesional (saat menjalankan kewenangannya). Data diperoleh melalui dokumen ${ }^{14}$. Data-data tersebut akan dianalisis secara diskriptif kualitatif.

\section{Hasil Penelitian dan Pembahasan}

\section{Kecenderungan Laporan}

Dalam konteks pengadilan yang fair, terutama berkenaan dengan Kode Etik dan Pedoman Perilaku hakim, laporan ke Komisi Yudisial memperlihatkan kecenderungan-kecenderungan tertentu yang menggambarkan adanya pelanggaran terhadap pengadilan yang fair, yaitu pelanggaran terhadap KE PPH.

Jumlah kumulatif pelanggaran dari tahun 2005 hingga Agustus 2014 adalah 10.833 kasus atau laporan. Dalam tujuh tahun pertama (2005-2011) terdapat peningkatan laporan secara signifikan, yaitu: 388 laporan pada 2005; meningkat menjadi 1717 laporan di tahun 2011. Sempat turun di 2012 (1470 laporan), tetapi kembali naik di tahun 2013 menjadi 2193. selengkapnya lihat grafik I:

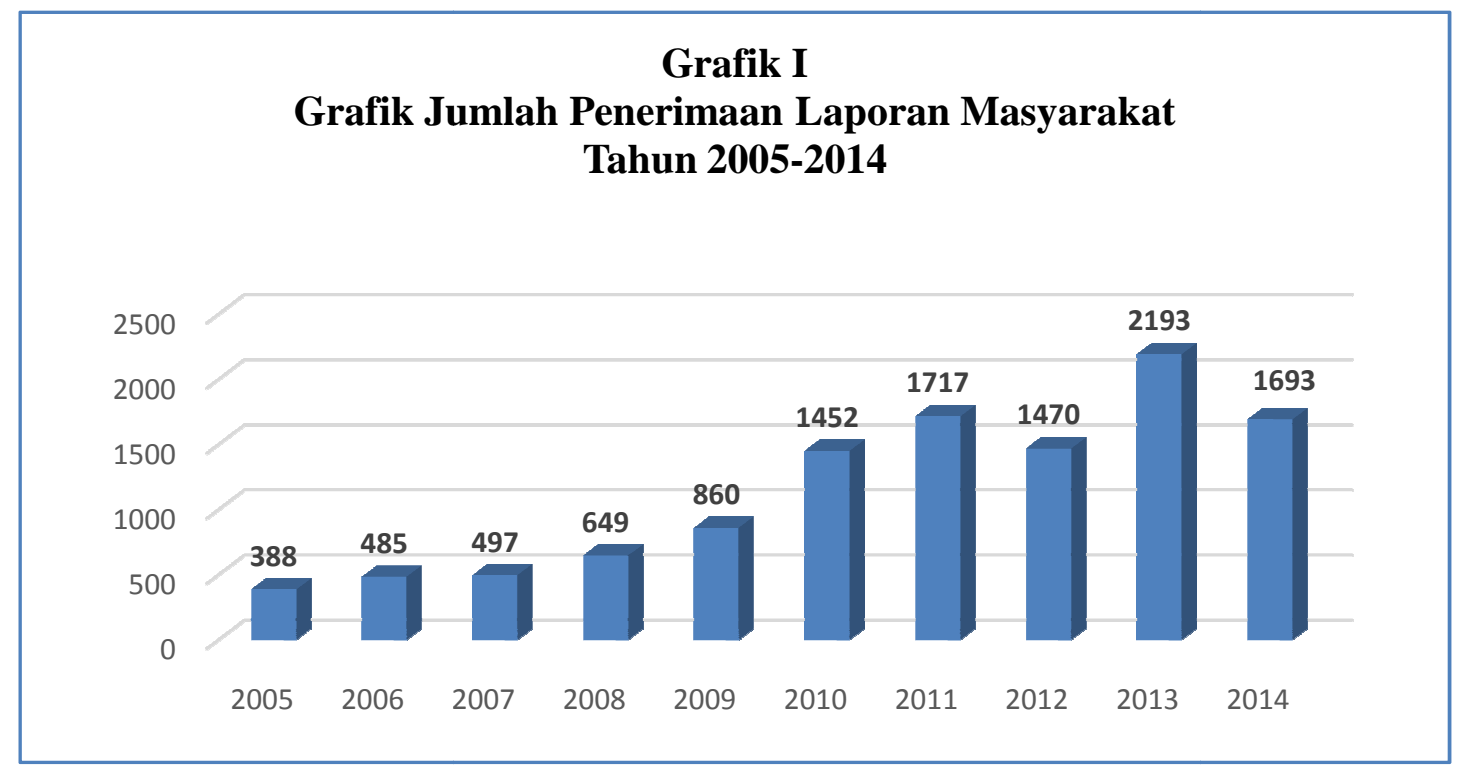

Sumber: Diolah dari laporan masyarakat ke Komisi Yudisial periode 2005-2014

${ }^{14}$ Dokumen penanganan laporan masyarakat ke Komisi Yudisial TI periode 2005-2014. 
Dari grafik tampak bahwa dari 2005 hingga 2011 laporan terus meningkat rata-rata 35 - 40\% setiap tahun. Bahkan peningkatan dari 2012 ke 2013 mencapai $50 \%$. Penyebab kecenderungan peningkatan laporan tersebut belum bisa dibaca secara detail, tetapi alasan umum kebanyakan pelapor adalah tidak percaya dengan proses pengadilan dan putusan hakim.

Apabila alasan ketidakpercayaan tersebut dikaitkan dengan Indeks Persepsi Negara Hukum Indonesia 2012 yang diluncurkan oleh Indonesian Legal Rountable (ILR) yang hanya mencapai $4,53^{15}$ atau hasil survei Lembaga Survei Indonesia (LSI) maka ketidakpercayaan itu memiliki alasan yang kuat.

Dalam survei ILR itu disebutkan juga bahwa 49\% responden tidak setuju kalau dikatakan hakim bersih. Bahkan $11 \%$ di antaranya sangat tidak setuju ${ }^{16}$. 40\% responden tidak setuju hakim independen; 7\% bahkan sangat tidak setuju. 33\% menganggap pengusaha sebagai pihak yang paling sering mempengaruhi hakim, kemudian Partai Politik (30\%), dan pemerintah (24\%).

Senada dengan hasil survei ILR, survei LSI juga menyebutkan bahwa tingkat ketidakpuasan masyarakat terhadap penegakan hukum di negeri ini semakin meningkat, yaitu berada pada angka 56\%; dan hanya 29,8\% yang menyatakan puas. Dalam kurun waktu 3 tahun terakhir prosentase tingkat ketidakpuasan masyarakat terhadap penegakan hukum di negeri ini terus mengalami kenaikan yang cukup signifikan. Januari 2010: 37,4\% ; Oktober 2010: 41,2\%. September 2011: 50,3\%; sementara Oktober 2012: 50,3\% dan yang terakhir April 2013,mencapai 56,0\%. Yang paling mencengangkan,tingkatketidakpuasan masyarakat di desa justru paling tinggi $(61,1 \%)$ dibanding masyarakat kota $(48,6 \%)$.

Ketidakpercayaan inilah yang memunculkan komentar atau pandangan negatif terhadap hakim dan mempertanyakan objektivitas hakim dalam melaksanakan tugas dan fungsinya. Apakah benar seorang hakim baik secara sadar maupun tidak sadar tidak akan dipengaruhi oleh faktor-faktor eksternal dalam memeriksa, mengadili dan memutus perkara. Pendapat ahli dan riset-riset telah banyak menyingkap variabel-variabel yang mempengaruhi hakim dalam memutus suatu perkara. Hakim bahkan potensial bersikap "prejudice" yang

\footnotetext{
$27-30$.

${ }^{15}$ Baca Rikardo Simarmata (ed) Indeks Persepsi Negara Hukum Indonesia 2012, ILR, Jakarta 2013, hlm. ${ }^{16}$ Ibid.
} 
disebabkan oleh latar belakang sosial dan politik kehidupannya sendiri dalam memutus setiap perkara yang diharapkan bersikap objektif dan imparsial. ${ }^{17}$

Disinilah relevansi kepercayaan (integritas) hakim dengan putusannya; bahwa putusan hakim itu lahir bukan hanya berdasarkan fakta-fakta yang terungkap dalam persidangan berdasarkan ketentuan peraturan perundangundangan saja, tetapi kombinasi antara fakta-fakta yang terungkap dalam persidangan berdasarkan ketentuan peraturan perundang-undangan tersebut dengan perilaku atau moralitas dari hakim itu sendiri. Cardozo menyatakan putusan hakim adalah salah satu dari realitas-realitas kehidupan yang ada, dan hukum adalah perilaku hakim yang belum tentu persis sama dengan perilaku hukum hakim lain, meskipun menghadapi kasus sejenis dan menggunakan ketentuan hukum yang sama. ${ }^{18}$

Selain faktor personalitas hakim, kepercayaan terhadap pengadilan (hakim) dipengaruhi juga oleh eksistensi kekuasaan kehakiman itu sendiri dalam sistem politik suatu negara. Dalam rezim otoritarian, ketidakpercayaan masyarakat kepada pengadilan sangat tinggi karena kuatnya intervensi kekuasaan terhadap pengadilan. Berbeda dengan pengadilan di negara-negara demokratis maju; pengadilan sangat independen dan dipercaya.

Itu sebabnya dalam transisi politik dari rezim otoritarian ke demokrasi, kedudukan kekuasaan kehakiman selalu mendapatkan perhatian utama untuk dibenahi, karena menjadi salah satu indikator untuk menilai apakah transisi rezim di suatu negera bergerak ke demokrasi atau tidak.

Luu Tien Dung pernah mengemukakan: "The judiciary in pre-transition regimes was 'dependent' or 'compromised' rather than independent. It failed to protect the rule of law and human rights. Many transitional countries have adopted the principle of separation of powers in the Constitution as a constitutional guarantee of the independence of the judiciary". 19

17 Abd Rasyid As’ad," "Prinsip Kekuasaan Kehakiman dan Independensi Peradilan”, Varia Peradilan No. 312, November 2011, hlm. 91.

18 Achmad Ali, Menguak Realitas Hukum: Rampai Kolom dan Artikel Pilihan Dalam Bidang Hukum, Kencana, Jakarta, 2008, hlm. 140-141.

19“Judicial Independence In Transitional Countries". UNDP, Democratic Governance Fellowship Programme, 2003, hlm. 8 
Dalam transisi politik di Indonesia pasca Orde Baru, kedudukan kekuasaan kehakiman di dalam Pasal 24A ayat (1) UUD 1945 ditegaskan merdeka yang menandakan adanya transisi rezim ke demokrasi secara signifikan. ${ }^{20}$

Menyusul perubahan UUD 1945 itu berubah dan dibentuk pula pelbagai peraturan perundang-undangan yang terkait dengan penyelenggaran kekuasaan kehakiman yaitu, Pertama, UU No. 24 tahun 2003 tentang Mahkamah Konstitusi. Kedua, UU No. 4 Tahun 2004 yang kemudian dirubah dengan UU No. 48 Tahun 2009 tentang Kekuasaan Kehakiman. Ketiga, UU No. 22 Tahun 2004 yang kemudian diubah dengan UU No. 18 Tahun 2011. Keempat, UU No. 5 Tahun 2004 yang kemudian diubah dengan UU No. 3 Tahun 2009 tentang Mahkamah Agung. Kelima, UU No. 8 Tahun 2004 yang kemudian diubah dengan UU No. 49 Tahun 2009 tentang Peradilan Umum. Keenam, UU No. 8 Tahun 2004 yang kemudian diubah dengan UU No. 51 Tahun 2009 tentang Peradilan Agama, dan Ketujuh, UU No. 9 Tahun 2004 yang kemudian diubah dengan UU No. 51 Tahun 2009 tentang Peradilan Tata Usaha Negara. Perubahan rezim yang diikuti oleh perubahan UUD 1945, serta pelbagai peraturan perundang-undangan di bawahnya yang makin menjamin kedudukan dan kewenangan kekuasaan kehakiman yang merdeka, belum secara signifikan berpengaruh terhadap meningkatnya kepercayaan masyarakat pada pengadilan. Terbukti laporan dengan alasan tidak percaya masih tinggi. Tampaknya perubahan di level substansi belum diikuti oleh perubahan institusi dan kultur penegak hukum menuju penegakan hukum yang fair dan objektif.

\section{Kecenderungan Jenis Perkara dan Wilayah}

Dari sudut jenis perkara atau persidangan yang dilaporkan, perkara pidana dan perdata menempati ranking satu dan dua. Selanjutnya persidangan

${ }^{20}$ Tafsir J. Johansyah atas rumusan Pasal 24 ayat (1) UUD 1945 dihubungkannya dengan penyelenggaraan peradilan; sehingga pengertiannya bukan pada kelembagaan, tetapi pada fungsi utama lembaga peradilan di tengah masyarakat, yaitu pemutus suatu sengketa hukum. Karena itu, kalimat berikutnya dalam Pasal konstitusi tersebut adalah 'berdasarkan hukum dan keadilan'.Baca Johansyah, J "Independensi Hakim di Tengah Benturan Politik dan Kekuasaan", dalamReformasi Peradilan dan Tanggung Jawab Negara, Komisi Yudisial, Jakarta, 2010, hlm. 73-74. 
Tata Usaha Negara, Militer, Agama, Tindak Pidana Korupsi, Niaga dan Perselisihan Hubungan Industrial (PHI). Selengkapnya lihat tabel I.

Tabel I

Laporan Berdasarkan Jenis Perkara

\begin{tabular}{|c|l|c|c|c|c|c|c|c|c|c|c|c|}
\hline \multirow{2}{*}{ No. } & Jenis & \multicolumn{8}{|c|}{ TAHUN } & \multirow{2}{*}{ Jumlah } \\
\cline { 3 - 12 } & Perkara & 2005 & 2006 & 2007 & 2008 & 2009 & 2010 & 2011 & 2012 & 2013 & 2014 & \\
\hline 1 & Pidana & 89 & 123 & 211 & 237 & 329 & 426 & 531 & 422 & 517 & 501 & 3386 \\
2 & Perdata & 224 & 295 & 202 & 322 & 391 & 745 & 699 & 608 & 871 & 799 & 5285 \\
3 & TUN & 28 & 31 & 28 & 27 & 57 & 90 & 82 & 82 & 102 & 104 & 631 \\
4 & Militer & 1 & 0 & 4 & 0 & 4 & 2 & 8 & 6 & 6 & 11 & 42 \\
5 & Agama & 1 & 11 & 14 & 7 & 18 & 21 & 32 & 45 & 58 & 44 & 251 \\
6 & Tipikor & 1 & 2 & 1 & 1 & 7 & 5 & 45 & 40 & 67 & 58 & 227 \\
7 & Niaga & 1 & 2 & 1 & 7 & 6 & 16 & 19 & 24 & 34 & 27 & 137 \\
8 & PHI & 0 & 0 & 16 & 17 & 36 & 26 & 40 & 23 & 43 & 36 & 237 \\
\hline
\end{tabular}

Sumber: Diolah dari laporan masyarakat ke Komisi Yudisial periode 2005-2014

Kecenderungan tingginya laporan perkara pidana dan perdata, menunjukkan banyaknya kasus pidana dan sengketa perdata dalam masyarakat kita; di samping tingginya tensi sensitifitas kedua perkara tersebut dibandingkan perkara-perkara lain. Hal tersebut tidak mengherankan karena pengadilan pidana dan perdata terkait dengan harkat dan martabat kemanusian, harta benda, hak, kewajiban dan bahkan nyawa manusia. Putusan hakim (pidana atau perdata) membawa akibat sangat jauh pada kehidupan para yustiabel dan atau orang lain yang terkena jangkauan keputusan itu. ${ }^{21}$

Muatan laporan masyarakat umumnya berisi antara lain: hakim berpihak pada penggugat atau tergugat, hakim bertemu salah satu pihak di luar sidang, hakim terima suap, hakim mengajukan pertanyaan menjerat, hakim mengabaikan bukti-bukti yang diajukan di persidangan, hakim tidak memasukkan keterangan saksi yang dinilai sangat penting dalam putusan, hakim sudah berprasangka, hakim membentak-bentak saksi dan atau terdakwa, dst.

Kekhawatiran atau ketakutan akan dampak dari putusan pidana atau perdata yang berbanding lurus dengan ketidakpercayaan pada hakim telah 
menjadikan perkara perdata sebagai perkara yang paling tidak fair, dan karena itu mendominasi laporan ke KY.

Sementara dari segi wilayah asal laporan, terdapat kecenderungan bahwa Daerah Khusus Ibu Kota Jakarta menempati ranking pertama sepuluh besar pemasok laporan dengan 2366 laporan. Menyusul berturut-turut; Jawa Timur (1271); Sumatera Utara (968); Jawa Barat (950); Jawa Tengah (621); Sulawesi Selatan (505); Riau (283); Sumatera Selatan (270); Nusa Tenggara Timur (241); dan Banten (230).

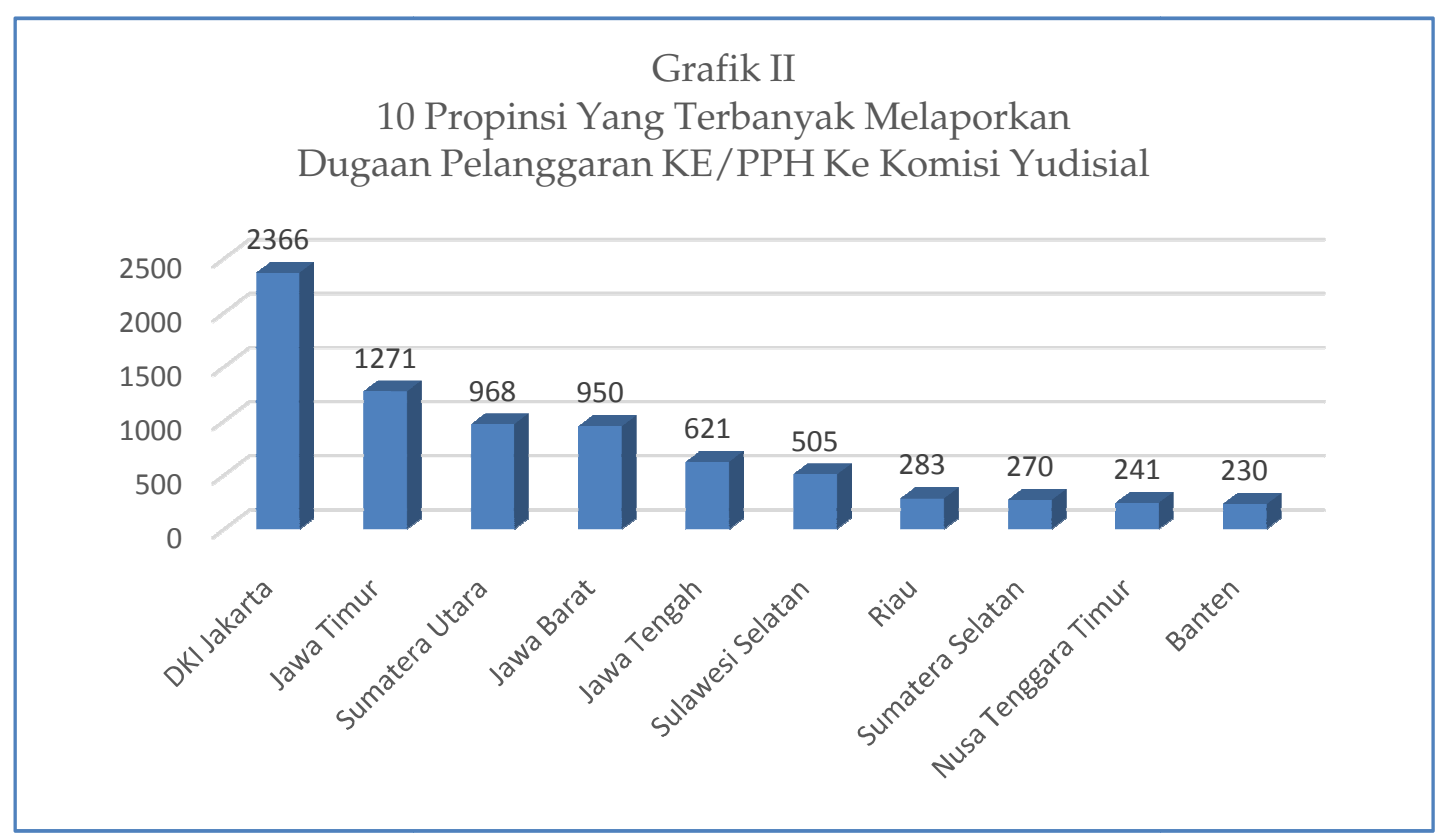

Sumber: Diolah dari laporan masyarakat ke Komisi Yudisial periode 2005-2014

Tinggi rendahnya laporan tidak terkait dengan jumlah penduduk, tetapi berkorelasi dengan asumsi umum masyarakat terhadap pengadilan di wilayahwilayah tersebut. Berdasarkan keterangan pelapor, mereka semenjak awal tidak yakin dan tidak percaya dengan objektivitas pengadilan di wilayah sepuluh besar tersebut karena telah cukup lama terbangun kepercayaan umum akan ketidakberesan pengadilan di daerah bersangkutan dalam memeriksa, mengadili dan memutus perkara.

Di sisi lain, tinggi rendahnya laporan tidak juga berkorelasi dengan jauh dekatnya institusi-institusi kontrol resmi negara maupun kekuatan kontrol lain seperti Pers dan LSM. Jakarta misalnya adalah wilayah dimana semua kekuatan 
kontrol (KY, LSM, Pers) tersedia dan bekerja, tetapi justru Jakarta menempati ranking pertama, dengan jumlah laporan dua kali lipat dari Jawa Timur.

Hasil pemantauan KY atas sepuluh besar pengadilan di atas memang terdapat situasi atau atmosfir kurang sehat, yang mendukung terbangunnya anggapan negatif pada pengadilan. Ini tentu sangat memprihatinkan karena atmosfir yang sehat akan berpengaruh pada hakim dan pengadilan, karena seperti dikemukakan Syamsudin, faktor-faktor lingkungan, sosial budaya akan berpengaruh dalam kehidupan seseorang hakim. ${ }^{22}$

\section{Kecenderungan Jenis Pelanggaran}

Berdasarkan data jenis pelanggaran yang terbukti berdasarkan hasil pleno pada periode 2005 s.d 2013 dapat diketahui persentase jenis pelanggaran KEPPH yang dilanggar, yaitu:

Tabel II

Jenis Butir Pelanggaran

\begin{tabular}{|c|l|c|}
\hline No. & \multicolumn{1}{|c|}{ Jenis Butir KE/PPH } & Jumlah (\%) \\
\hline 1 & Berperilaku Adil & $12.25 \%$ \\
2 & Berperilaku Jujur & $10.72 \%$ \\
3 & Berperilaku Arif dan Bijaksana & $5.47 \%$ \\
4 & Bersikap Mandiri & $0.22 \%$ \\
5 & Berintegritas Tinggi & $7.44 \%$ \\
6 & Bertanggung Jawab & $1.53 \%$ \\
7 & Menjunjung Tinggi Harga Diri & $3.50 \%$ \\
8 & Berdisiplin Tinggi & $22.10 \%$ \\
9 & Berperilaku Rendah Hati & $0.44 \%$ \\
10 & Bersikap Profesional & $36.32 \%$ \\
\hline
\end{tabular}

Dari tabel terlihat adanya lima besar kecenderungan pelanggaran KE PPH yang ditemukan, yaitu: tidak profesional (36,32\%), tidak berdisiplin tinggi $(22,10 \%)$, tidak adil $(12,72 \&)$, tidak jujur $(10,72 \%)$, dan tidak berintegritas tinggi $(7,44 \%)$.

22 M. Syamsudin, Konstruksi Baru Budaya Hukum Hakim Berbasis Hukum Progresif, Kencana Prenada Media Group, Jakarta, 2012, hlm. 93. 
Temuan hakim tidak profesional yaitu: keliru membuat putusan, mengabaikan fakta yang terungkap di persidangan dengan tidak memasukkannya dalam pertimbangan putusan, menggunakan undang-undang atau peraturan pemerintah yang sudah dicabut atau dibatalkan oleh Mahkamah Konstitusi (MK).

Jenis pelanggaran hakim tidak berdisiplin tinggi yaitu: hakim keliru menerapkan hukum acara, seperti mengabulkan permohonan pra peradilan oleh pihak yang tidak memenuhi ketentuan Pasal 80 KUHAP, memutuskan menghentikan penyidikan suatu tindak pidana dalam mekanisme pra pradilan yang bertentangan dengan Pasal 77 dan $80 \mathrm{KUHAP}$, serta proses persidangan yang lama dan berlarut-larut.

Hakim tidak adil: menunjukkan sikap dan atau tindakan memihak, tidak memberikan kesempatan yang sama dengan para pihak yang sedang berpekara, berkomunikasi dan atau bertemu dengan salah satu pihak yang sedang berperkara di pengadilan dan di luar pengadilan. Itulah wujud dari prilaku hakim yang tidak sejalan dengan prinsip The Four Commandments for Judges, yaitu: 1. to hear corteusly (mendengar dengan sopan dan beradab; 2. to answer wisely (menjawab dengan arif dan beradab); 3. to consider soberly ( mempertimbangkan tanpa terpengaruh apapun); 4. to decide impartially (memutus tidak berat sebelah). ${ }^{23}$

Tidak jujur: meminta atau menerima hadiah, pemberian, pinjaman dari advokat, dari terdakwa, dari saksi, selingkuh, judi, mengkonsusmi narkoba. Sementara perilaku tidak berintegritas tinggi: menunda eksekusi tanpa dasar atau alasan yang dibenarkan oleh UU atau peraturan MA, serta menggunakan wibawa jabatan untuk kepentingan pribadi dan keluarga.

Kesepuluh prinsip KEPPH tersebut di atas merupakan kristalisasi nilai dari tuntutan keharusan pengadilan yang mandiri, netral (tidak memihak), kompeten, transparan, akuntabel dan berwibawa yang mampu menegakkan wibawa hukum, pengayoman hukum, kepastian hukum dan keadilan sebagai persyaratan mutlak dalam sebuah negara hukum. ${ }^{24}$

7.

${ }^{23}$ Wildan Suyuthi, Kode Etik, Etika Profesi dan Tanggung Jawab Hakim, Pusdiklat MA-RI, Jakarta, 2004, hlm.

${ }^{24}$ Pembukaan Kode Etik Pedoman Perilaku Hakim alenia pertama. 
KE PPH menjadi kewajiban kumulatif hakim yang mengikat untuk dijalankan karena telah menjadi norma yang ditetapkan untuk mengarahkan atau memberi petunjuk kepada anggotanya bagaimana seharusnya berbuat dan berperilaku sekaligus menjamin mutu moral profesi itu di mata masyarakat;25 sekaligus menjadi hak masyarakat dan setiap orang yang sedang berperkara. Dikatakan hak, karena pihak yang sedang berperkara menggantungkan masa depan harta benda bahkan kelangsungan hidupnya pada proses dan putusan hakim yang fair. Begitu pula dengan masyarakat umum yang potensial berurusan dengan hukum, berhak mendapatkan kepercayaan serupa sehingga kelak jika berurusan dengan hukum, masyarakat telah dibekali kepercayaan akan proses dan putusan yang adil.

Itulah aspek mendasar dari ada tidaknya kepercayaan masyarakat terhadap proses dan putusan hakim. Jika saja hal ini bisa dijaga konsistensinya maka kepercayaan masyarakat terhadap pengadilan sebagai tempat menyelesaikan sengketa menjadi kuat. Dampak lebih jauh akan timbul keengganan masyarakat menggunakan upaya hukum banding atau kasasi, sebagaimana masyarakat Jepang atau Jerman yang memiliki tingkat kepercayaan tinggi pada pengadilan sehingga permohonan banding atau kasasi di kedua negara tersebut berkisar 4 - 5 \% saja.

Sebaliknya apabila ketidakpercayaan meluas dan menguat, maka selain pengadilan kehilangan kepercayaan dan kewibawaannya, akan kehilangan pula kegunaannya sebagai mekanisme penyelesaian sengketa. Barangkali inilah makna lain dari ungkapan Rose Elizabeth Bird (Hakim negara bagian California) ketika mengatakan: "If our courts lose their authority and their rulings are no longer respected, there will be no one left to resolve the divisive issue that can rip the social fabric apart. The courts are a safety valve without which no democratic society can surve" (jika peradilan kita sudah kehilangan kewibawaannya dan putusannya tidak lagi dihiraukan, maka tentu saja tidak akan tersisa sesuatu apapun yang mampu menyelesaikan masalah yang dapat memecah belah dan merobek-robek tatanan sosial. ${ }^{26}$ Karena itu, sebagai pemegang kekuasaan kehakiman, hakim harus memiliki

${ }^{25}$ K. Bertens, Etika, Gramedia Pustaka Utama, Jakarta, 2005, hlm. 11-15.

26 Ahmad Ali, Menguak Realitas Hukum: Rampai Kolom dan Artikel Pilihan Dalam Bidang Hukum, Kencana, Jakarta, 2008, hlm. 1. 
kewibawaan, sebab hanya dengan begitu berbagai putusannya dihiraukan dan dihormati masyarakat.

Mungkin saja ungkapan tersebut berlebihan karena menjadikan proses hukum sebagai satu-satunya mekanisme penyelesaian masalah, tetapi pesan moral pernyataan itu adalah bahwa ketidakpercayaan dapat meruntuhkan harapan. ${ }^{27}$

Kepercayaan tidak bisa dicapai dengan mudah. Hakim harus membangun rangkaian perilaku tidak tercela sepanjang karirnya. Dua di antaranya yang bersifat universal dan intisari dari sepuluh prinsip KE PPH adalah independen dan imparsial.

Independensi akan tergambar pada ada atau tidaknya kehormatan hakim yang bersangkutan. Kehormatan adalah kemuliaan atau nama baik yang senantiasa harus dijaga dan dipertahankan dengan sebaik-baiknya oleh para hakim dalam menjalankan fungsi pengadilan. Hakim yang memiliki kehormatan dalam kedinasan dapat diidentifikasi melalui kedisiplinannya dalam menghadiri sidang, sikap dan perilakunya dalam persidangan, kata dan ucapannya, kecermatan dan kesungguhan dalam memeriksa, mengadili dan memutus perkara; termasuk di dalamnya pertimbangan yang melandasi putusan itu, yang bukan saja berlandaskan peraturan perundang-undangan, tetapi juga rasa keadilan dan kearifan dalam masyarakat.

Kedua, tergambar pada keluhuran martabatnya, yaitu tingkat harkat kemanusiaan atau harga diri yang mulia yang sepatutnya tidak hanya dimiliki, tetapi harus dijaga dan dipertahankan oleh hakim melalui sikap tindak atau perilaku yang berbudi pekerti luhur. Hanya dengan sikap tindak atau perilaku yang berbudi pekerti luhur itulah keluhuran martabat hakim dapat dijaga dan ditegakkan. Ketiga, tergambar dari tanggapan atas reaksi individu yang terwujud dalam gerakan (sikap) dan ucapan yang sesuai dengan apa yang dianggap pantas oleh kaidah-kaidah hukum yang berlaku.

Pentingnya independensi peradilan dijamin oleh negara terlihat dalam pernyataan Basic Principles On The Independenceof The Judiciary, yang menegaskan

27 Suparman Marzuki, “Kekuasaan Kehakiman: Independensi, Akuntabilitas dan Pengawasan Hakim”, Dalam Dialektika Pembaharuan Sistem Hukum Indonesia, Komisi Yudisial, 2012, hlm. 295. 
bahwa independensi kekuasaan kehakiman (peradilan) harus ditetapkan dalam konstitusi atau undang-undang negara, dan menjadi tugas pemerintah serta lembaga-lembaga lainnya untuk menghormati dan menjaganya. ${ }^{28}$

Independensi kekuasaan kehakiman adalah prinsip universal yang dimuat dalam pelbagai instrumen hukum international, antara lain dalam Pasal 10 Deklarasi Universal HAM yang berbunyi:

"Setiap orang berhak dalam persamaan sepenuhnya didengarkan suaranya di muka umum dan secara adil oleh pengadilan yang merdeka dan tak memihak, dalam hal menetapkan hak-hak dan kewajiban-kewajibannya dan dalam setiap tuntutan pidana yang ditujukan kepadanya."

Sementara Pasal 8 berbunyi: Setiap orang berhak atas pengadilan yang efektif oleh hakim-hakim nasional yang kuasa terhadap tindakan perkosaan hakhak dasar, yang diberitakan kepadanya oleh undang-undang dasar negara atau undang-undang.

Selain itu dimuat juga dalam Pasal 14 Kovenan Internasional Hak Sipil Politik, paragraf 27 deklarasi Viena 1993; dalam Universal Declaration on the Independence of Justice, Montreal 1983, serta dalam The United Nations Basic Principles on the Independence of the Judiciary, The Syracuse Draft Principle on Independence of the Judiciary which was prepared by a Committee of Jurists and the International Commission of Jurists at Syracuse.

Dalam artikel No. 2 pada Statute of the International Court of Justice dinyatakan:

"The Court shall be composed of a body of independent judges, elected regardless of their nationality from among persons of high moral character, who possess the qualifications required in their respective countries for appointment to the highest judicial offices, or are juris consults of recognized competence in international law."

Statuta tersebut menyatakan bahwa peradilan harus ditopang oleh hakimhakim yang independen, yaitu mereka yang dipilih diantara anak bangsa yang memiliki integritas moral yang tinggi. Memiliki kualifikasi yang tinggi untuk mewujudkan supremasi lembaga peradilan.

${ }^{28}$ Basic Principles on the Independence of the Judiciary, 1985. 
Basic Principles On Independenceof The Judiciary, yang diajukan oleh Majelis Umum PBB (Resolusi 40/32 tanggal 29 November 1985 dan resolusi 40/146 tanggal 13 Desember 1985), serta Beijing Statement Of Principles Of The Independence The Law Asia Region Of The Judiciary di Manila tanggal 28 Agustus 1997, menegaskan bahwa: Pertama, kehakiman merupakan institusi nilai yang tertinggi pada setiap masyarakat. Kedua, kemerdekaan hakim mempersyaratkan hakim memutuskan perkara sepenuhnya atas dasar pemahaman undang-undang dan terbebas dari pengaruh dari manapun, baik langsung maupun tidak langsung. Hakim memiliki yurisdiksi atas segala isu yang memerlukan keadilan. Hakim juga harus memiliki judicial discretion. Henry J. Abraham menyatakan ${ }^{29}$ :

"Enlightened by intelligence and learning,controlled by sound principles of law, of firm courage combined with the calmness, of a cool mind, free from partiality, not swayed by sympathy nor warped by prejudice nor moved by any kind of influence save alone the overwhelming passion to do that which is just...")

Terlaksana dan terjaganya independensi hakim tergantung pula pada kekuatan kepribadiannya untuk menjaga imparsialitasnya, menjaga pandangan dan pikirannya tetap fokus pada dirinya sebagai hakim yang diberi mandat negara untuk mengadili sehingga ia harus benar-benar berdiri di atas kakinya sendiri tanpa berpaling. Dalam kaitan itu, Benjamin N. Cardozo mengatakan ${ }^{30}$ :

My duty as judge may be to objectify in law, not my own aspirations and convictions and philosophies, but the aspirations and convictions and philosophies of the men and women of my time. Hardly shall I do this well if my own sympathies and beliefs and passionate devotions are with a time that is past.

Bagi hakim Benjamin N. Cardozo, putusan-putusannya bukan perwujudan aspirasi pribadinya, pendirian pribadinya atau penerapan falsafah pribadinya, melainkan perwujudan dari aspirasi, pendirian dan falsafah masyarakat pada waktu dan dimana putusan itu dijatuhkan. Karena itu, faktor kendali pikiran hakim dengan basis falsafah moral (moral philosophy) dapat memberikan arahan dalam berpikir dan bertindak para hakim sehingga hakim mendapatkan kepercayaan atas profesi dan putusannya. Pada bagian lain, hakim juga

${ }^{29}$ Henry J. Abraham, The Judicial Process, Oxford University Press, New York, 1993, hlm. 97. 70.

${ }^{30}$ Benjamin N Cardozo, The Nature of The Judicial Process, Yale University Press, New Haven, 1921, hlm. 
diwajibkan tidak memihak di dalam maupun di luar pengadilan; dilarang memberikan kesan bahwa salah satu pihak yang tengah berperkara atau kuasanya termasuk penuntut dan saksi berada dalam posisi yang istimewa untuk mempengaruhi hakim bersangkutan.

Hakim dilarang menunjukkan rasa suka atau tidak suka, keberpihakan, prasangka, atau pelecehan terhadap suatu ras, jenis kelamin, agama, asal kebangsaan, perbedaan kemampuan fisik atau mental, usia atau status sosial ekonomi maupun atas dasar kedekatan hubungan dengan pencari keadilan atau pihak-pihak yang terlibat dalam proses peradilan baik melalui perkataan maupun tindakan. Dilarang bersikap, mengeluarkan perkataan atau melakukan tindakan lain yang dapat menimbulkan kesan memihak. Dengan kata lain, hakim tidak saja berkerja secara imparsial (to be impartial), tetapi juga terlihat bekerja secara imparsial (to appear to the impartial). 31

UU Pokok Kekuasaan Kehakiman No. 48 Tahun 2009 Pasal 17 ayat (3, 4 dan 5) menegaskan keharusan hakim mengundurkan diri apabila terikat hubungan keluarga sedarah atau semenda sampai derajat ketiga, atau hubungan suami atau istri meskipun telah bercerai, dengan ketua, salah seorang hakim anggota, jaksa, advokat, panitera, atau dengan pihak yang diadili atau advokat, atau mempunyai kepentingan langsung atau tidak langsung dengan perkara yang sedang diperiksa, baik atas kehendaknya sendiri maupun atas permintaan pihak yang berperkara.

Bila terjadi pelanggaran terhadap imparsialitas, maka putusan dinyatakan tidak sah dan terhadap hakim atau panitera yang bersangkutan dikenakan sanksi administratif atau dipidana sesuai ketentuan peraturan perundang-undangan (ayat 5). Selanjutnya perkara bersangkutan diperiksa kembali dengan susunan majelis hakim yang berbeda.

Hakim tidak bisa hanya diasumsikan imparsial sampai ada bukti yang mengatakan sebaliknya bahwa hakim itu tidak imparsial (objektif imparsialitas) karena syarat imparsialita sobyektif sesunguhnya adalah harus ada jaminan yang

31 Ofer Raban, Modern Legal Theory and Judicial Impartiality, Routledge-Cavendish, London, 2003, hlm.1. 
layak dari hakim untuk mengesampingkan keraguan tentang imparsialitas dirinya dan proses pengadilan.

O. Hood Phillips dan kawan-kawan menyatakan, "The impartiality of the judiciary recognised as an important, if not the most important element". Dalam praktik, ketidakberpihakan atau impartialitas itu sendiri mengandung makna dibutuhkannya hakim yang tidak saja berkerja secara imparsial (to be impartial), tetapi juga terlihat bekerja secara imparsial (to appear to the impartial). 32

Agar hakim dapat menyelesaikan masalah yang dihadapkan kepadanya secara imparsial berdasarkan hukum yang berlaku, maka hakim dalam mengambil keputusan terikat pada fakta-fakta yang relevan dan kaidah hukum yang menjadi landasan yuridis keputusannya.

Kokoh tidaknya independensi dan imparsialitas tersebut ditentukan oleh ada tidaknya integritas dan kompetensi personal hakim bersangkutan. Ketiadaan integritas dan kompetensi bisa memunculkan empat faktor subjetif hakim, yaitu: (1)sikap perilaku yang apriori, yakni adanya sikap hakim yang sejak semula sudah menganggap bahwa terdakwa yang diperiksa dan diadili adalah orang yang memang telah bersalah sehingga harus dipidana; (2) sikap perilaku emosional, yakni putusan pengadilan akan dipengaruhi oleh perangai hakim. Hakim yang mempunyai perangai mudah tersinggung akan berbeda dengan perangai hakim yang tidak mudah tersinggung. Demikian pula putusan hakim yang mudah marah dan pendendam akan berbeda dengan putusan seorang hakim yang sabar; (3) Sikap arrogance power, yakni sikap lain yang memengaruhi suatu putusan adalah "kecongkakan kekuasaan", disini hakim merasa dirinya berkuasa dan pintar, melebihi orang lain (jaksa, pembela apalagi terdakwa); (4) Moral, yakni moral seorang hakim karena bagaimanpun juga pribadi seorang hakim diliputi oleh tingkah laku yang didasari oleh moral pribadi hakim tersebut terlebih dalam memeriksa serta memutuskan suatu perkara. ${ }^{33}$

Pelanggaran terhadap prinsip imparsial dan atau independen tersebar dan tersamar dalam pelanggaran point KE PPH tidak adil, tidak mandiri dan tidak profesional. Sayangnya, pengadilan kita belum pernah memutuskan atau

${ }^{32}$ Ibid.

33 Antonius Sujata, Hati Nurani Hakim dan Putusannya, PT Citra Aditya Bakti, Jakarta, 2007, hlm. 94. 
membatalkan putusan pengadilan yang dilakukan dengan melanggar Kode Etik atau prinsip pengadilan yang fair. Berbeda dengan negara-negara maju yang menjamin dengan kuat proses pengadilan yang fair itu.

Yurisprudensi Pengadilan HAM Eropa dalam perkara Mc Gonner Vs. Inggris sangat penting dikutif secara ringkas disini. ${ }^{34}$

“Dalam perkara ini Pemohon membeli sebidang tanah di Guernsey Inggris, kemudian pemohon mengubah tanah tersebut menjadi lahan pertanian. Pemerintah dan parlemen lokal Guernsey mengeluarkan peraturan tata kota, dan ternyata tanah milik pemohon menjadi obyek pembangunan sehingga tanah pemohon terancam digusur.

Setelah keberatan pemohon ditolak dinas tata kota setempat, pemohon mengajukan banding ke Pengadilan Kerajaan (the Royal Court). Komposisi hakim di Royal Court terdiri dari the Baillif (badan pemerintah dan parlemen) dan tujuh juri. Pimpinan sidang perkara tersebut adalah Mr. Graham Dorey, yang sebelumnya pernah terlibat dalam perumusan peraturan tata kota yang menggusur tanah milik pemohon ketika dia menjabat sebagai ketua parlemen dan pada waktu itu juga dia menjabat sebagai wakil ketua Bailiff. Akan tetapi permohonan pemohon ditolak oleh the Royal Court, dengan alasan aturan tersebut sudah sesuai dengan hukum.

Pemohon lalu menempuhupayahukum secara domestik di Inggris, menguji putusan the Royal Court ke Pengadilan HAM Eropa dengan argumen the Royal Court tidak independen dan imparsial karena terdapat hakim dari badan (theBaillif) yang juga menjalankan fungsi non-yudicial (fungsi legislatif dan eksekutif). Pengadilan HAM Eropa mengabulkan permohonan pemohon, dan menyatakan the Royal Court tidak imparsial karena terdapat hakim yang pernah menjabat ketua parlemen ketika aturan tentang tata kotadisahkan

Pengadilan HAM Eropa menekankan pentingnya melihat latar belakang hakim yang memutus perkara; apakah hakim tersebut sebelumnya pernah terlibat perkara dengan pemohon. Ataukah hakim tersebut yang berasal dari badan pemerintah atau legislatif yang pernah berurusan dengan perkara si pemohon. Di sini kapasitas personal hakim harus betul-betul terbebas dari 
kepentingan pemerintahan maupun legislatif. Penting juga untuk mempertimbangkan kembali hakim-hakim yang berasal dari badan yang mempunyai fungsi ganda (eksekutif maupun legislatif).

\section{Kecenderungan Sanksi}

Sementara itu, selama periode 2005 s.d April 2014 Komisi Yudisial telah merekomendasikan usul penjatuhan sanksi terhadap hakim yang terbukti melakukan pelanggaran $\mathrm{KEPPH}$, antara lain:

Tabel III

Usul Penjatuhan Sanksi

\begin{tabular}{|l|l|l|l|l|l|l|l|l|l|l|l|l|}
\hline \multirow{2}{*}{ No. } & \multirow{2}{*}{ Jenis Sanksi } & \multicolumn{7}{|c|}{ Tahun } & \multirow{2}{*}{ Jumlah } \\
\cline { 3 - 14 } & & 2005 & 2006 & 2007 & 2008 & 2009 & 2010 & 2011 & 2012 & 2013 & 2014 & \\
\hline 1 & Sanksi Ringan & 6 & 5 & 1 & 0 & 7 & 45 & 8 & 19 & 59 & 90 & 240 \\
2 & Sanksi Sedang & 2 & 5 & 7 & 1 & 6 & 16 & 7 & 3 & 3 & 22 & 72 \\
3 & Sanksi Berat & 0 & 0 & 1 & 1 & 3 & 12 & 1 & 5 & 9 & 10 & 42 \\
\hline
\end{tabular}

Sumber: Diolah dari laporan masyarakat ke Komisi Yudisial periode 2005-2014

Selama periode 2005-2014, KY merekomendasikan 240 sanksi ringan, 72 sanksi sedang, dan 42 sanksi berat. Apabila dibandingkan antara periode 20052010 dengan 2011-April 2014 terdapat kecenderungan sebagai berikut: lima tahun pertama (2005-2010) terdapat 64 rekomendasi sanksi ringan; 37 rekomendasi sanksi sedang; dan 17 rekomendasi sanksi berat. Pada periode 2011-2014 terdapat: 176 rekomendasi sanksi ringan; 35 rekomendasi sanksi sedang; dan 25 rekomenasi sanksi berat.

Jenis sanksi ringan yang direkomendasikan; 90 persen teguran tertulis, dan hanya 10 persen pernyataan tidak puas secara tertulis. Untuk sanksi sedang; seluruhnya berupa hakim non palu antara 3 - 6 bulan. Sedangkan untuk sanksi berat; 60 persen non palu 1 - 2 tahun; sisanya 40 persen berupa usul pemberhentian dengan hak pensiun dan usul pemberhentian dengan tidak hormat.

Khusus terhadap rekomendasi sanksi berat (pemberhentian dengan hak pensiun atau pemberhentian dengan tidak hormat) telah diselenggarakan sidang Majelis Kehormatan Hakim (MKH) sebanyak 29 kali semenjak ditandatanganinya Keputusan Bersama Ketua Mahkmah Agung RI dan Ketua Komisi Yudisial RI 
Nomor: 129/KMA/IX/2009- Nomor 04/SKB/P.KY/IX/2009 tanggal 8 September 2009.

Tahun 2009, 3 orang hakim dikenai sanksi berat berupa diberhentikan 1 orang; 2 orang non palu 20 dan 24 bulan. Tahun 2010: 4 orang diberhentikan tidak hormat; 1 orang non palu 24 bulan. Tahun 2011: 2 orang diberhentikan tidak hormat; 1 orang non palu 24 bulan, dan 1 orang dikurangi tunjangan kinerja 75\% selama 3 bulan. Tahun 2012:1 orang diberhentikan tidak hormat; 1 orang non palu 24 bulan, dan 1 orang non palu 12 bulan. Tahun 2013: 4 orang diberhentikan tidak hormat; 2 orang non palu 24 bulan, dan 1 orang non palu 12 bulan. Tahun 2014: 7 orang diberhentikan dengan hak pensiun; 2 orang diberhentikan tidak hormat; 3 orang non palu selama 4-6 bulan.

Sidang Majelis Kehormatan Hakim $(\mathrm{MKH})$ telah dilaksanakan 29 kali semenjak tahun 2009 s.d September 2014, dengan rincian sebagai berikut:

Tabel IV

Sidang Majelis Kehormatan Hakim

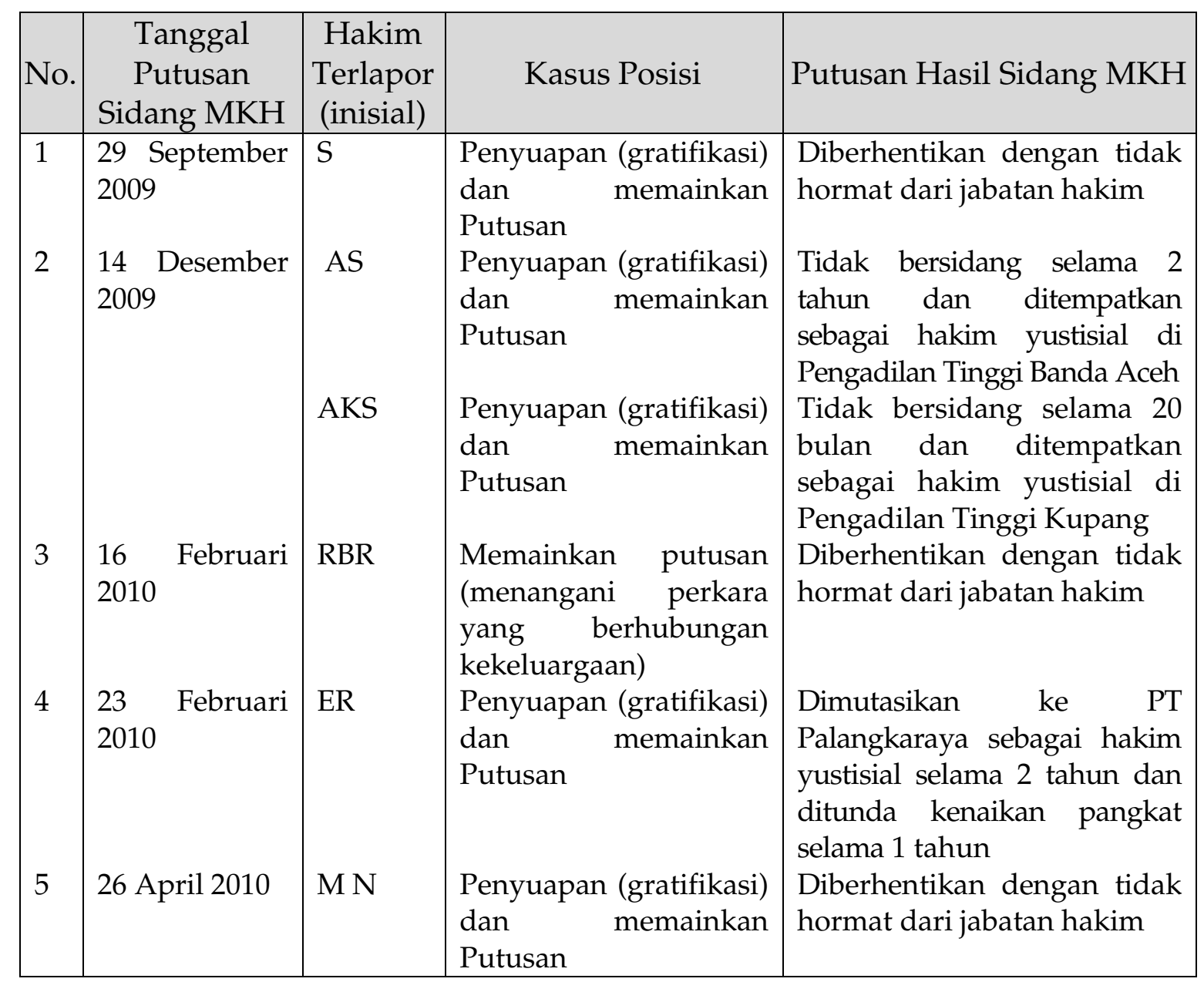




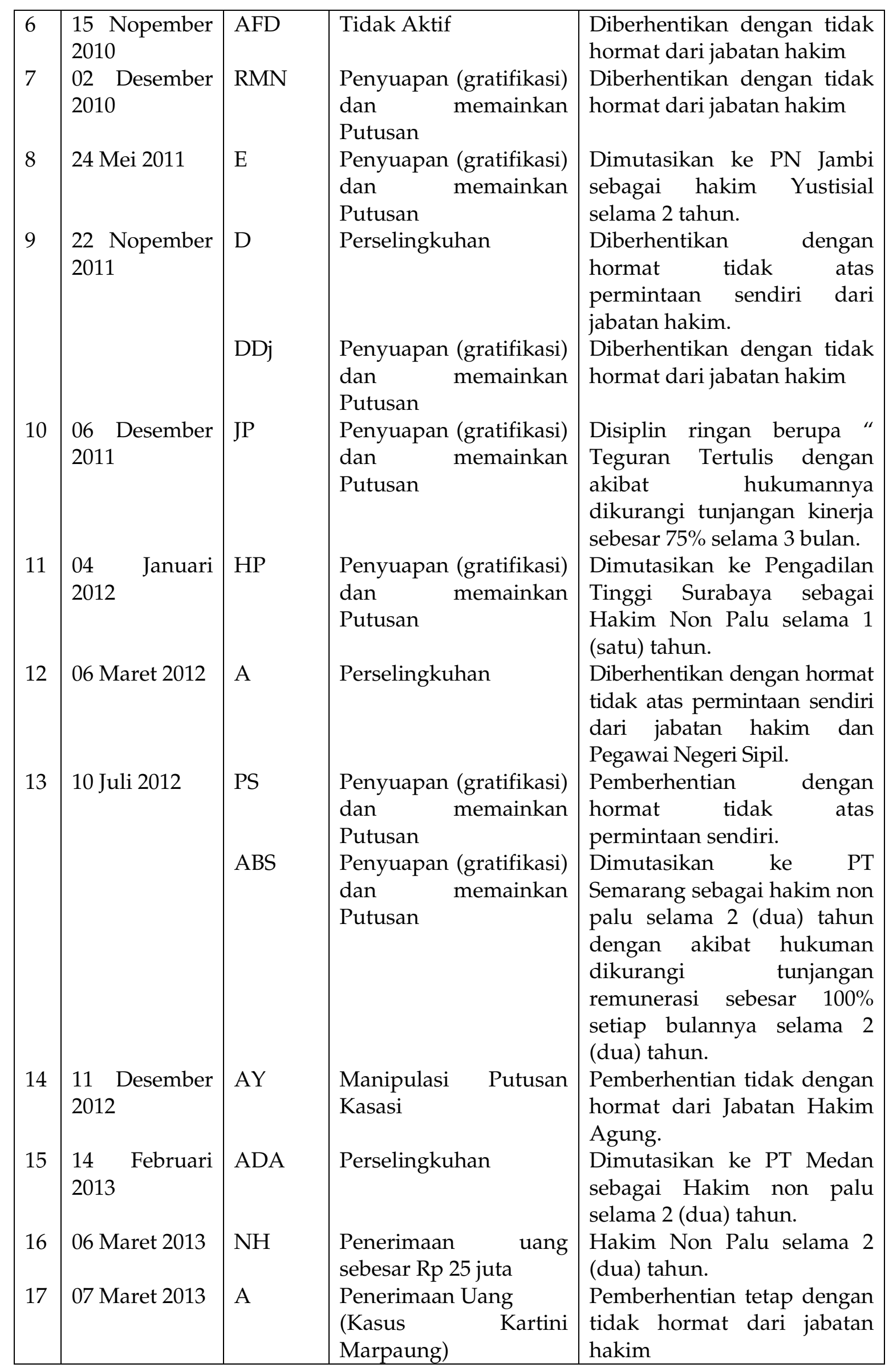




\begin{tabular}{|c|c|c|c|c|}
\hline & & AS & Perselingkuhan & Pemberhentian tetap dengan \\
\hline \multirow[t]{2}{*}{18} & $\begin{array}{l}06 \text { Nopember } \\
2013\end{array}$ & VN & Perselingkuhan & $\begin{array}{l}\text { Pemberhentian tetap dengan } \\
\text { hormat dengan hak pensiun }\end{array}$ \\
\hline & & RLT & $\begin{array}{l}\text { Mengkonsumsi } \\
\text { Narkoba }\end{array}$ & $\begin{array}{l}\text { Pemberhentian tetap dengan } \\
\text { hormat dengan hak pensiun }\end{array}$ \\
\hline 19 & $\begin{array}{l}07 \text { Nopember } \\
2013\end{array}$ & SMOS & $\begin{array}{l}\text { Perselingkuhan dan } \\
\text { perjudian }\end{array}$ & $\begin{array}{l}\text { Hakim Non Palu selama } 1 \\
\text { (satu) tahun }\end{array}$ \\
\hline 20 & $\begin{array}{ll}25 & \text { Pebruari } \\
2014 & \end{array}$ & PJ & $\begin{array}{l}\text { Penerimaan uang } \\
\text { sebesar Rp } 20 \text { juta dan } \\
\text { bertemu pihak yang } \\
\text { berperkara }\end{array}$ & $\begin{array}{l}\text { Hakim Non palu selama } 4 \\
\text { (empat) bulan, Tidak } \\
\text { diberikan tunjangan sebagai } \\
\text { hakim selama menjalani } \\
\text { sanksi. }\end{array}$ \\
\hline \multirow[t]{2}{*}{21} & $\begin{array}{ll}27 & \text { Pebruari } \\
2014 & \end{array}$ & PSL & $\begin{array}{l}\text { Mengkonsumsi } \\
\text { Narkoba }\end{array}$ & $\begin{array}{l}\text { Pemberhentian tetap dengan } \\
\text { hak pensiun }\end{array}$ \\
\hline & $\begin{array}{l}\text { Diajukan oleh } \\
\text { MA }\end{array}$ & M. RL & Perselingkuhan & $\begin{array}{l}\text { Pemberhentian tetap dengan } \\
\text { hak pensiun }\end{array}$ \\
\hline \multirow[t]{2}{*}{22} & 04 Maret 2014 & M & Perselingkuhan & $\begin{array}{l}\text { Pemberhentian tetap dengan } \\
\text { hak pensiun }\end{array}$ \\
\hline & & $\mathrm{E}$ & Perselingkuhan & $\begin{array}{l}\text { Pemberhentian tetap dengan } \\
\text { hak pensiun }\end{array}$ \\
\hline \multirow[t]{2}{*}{23} & 05 Maret 2014 & $\mathrm{~J}$ & Perselingkuhan & $\begin{array}{l}\text { Pemberhentian tetap dengan } \\
\text { hak pensiun }\end{array}$ \\
\hline & & PR & Perselingkuhan & $\begin{array}{l}\text { Pemberhentian dengan hak } \\
\text { pensiun }\end{array}$ \\
\hline 24 & 06 Maret 2014 & RC & $\begin{array}{l}\text { Penerimaan Gratifikasi } \\
\text { Terkait Bantuan Sosial } \\
\text { Bandung }\end{array}$ & $\begin{array}{l}\text { Pemberhentian tetap dengan } \\
\text { tidak hormat }\end{array}$ \\
\hline 25 & $\begin{array}{ll}12 & \text { Agustus } \\
2014 & \end{array}$ & BS & $\begin{array}{l}\text { Penerimaan Uang dan } \\
\text { bertemu dengan para } \\
\text { pihak }\end{array}$ & $\begin{array}{l}\text { Hakim non palu selama } 6 \\
\text { (enam) bulan, tidak } \\
\text { diberikan tunjangan sebagai } \\
\text { hakim selama menjalani } \\
\text { sanksi }\end{array}$ \\
\hline 26 & $\begin{array}{l}09 \text { September } \\
2014\end{array}$ & $\mathrm{PN}$ & $\begin{array}{l}\text { Indisipliner/Mangkir } \\
\text { Kerja }\end{array}$ & $\begin{array}{l}\text { Hakim Non Palu selama } 5 \\
\text { (lima) bulan }\end{array}$ \\
\hline 27 & $\begin{array}{l}10 \text { September } \\
2014\end{array}$ & NS & $\begin{array}{l}\text { Indisipliner/Mangkir } \\
\text { Kerja }\end{array}$ & $\begin{array}{l}\text { Pemberhentian tetap dengan } \\
\text { hak pensiun }\end{array}$ \\
\hline 28 & $\begin{array}{l}11 \text { September } \\
2014\end{array}$ & I & $\begin{array}{l}\text { Indisipliner/Mangkir } \\
\text { Kerja }\end{array}$ & $\begin{array}{l}\text { Pemberhentian tidak dengan } \\
\text { hormat sebagai hakim dan } \\
\text { sebagai PNS }\end{array}$ \\
\hline 29 & $\begin{array}{l}18 \text { September } \\
2014\end{array}$ & $\mathrm{JE}$ & $\begin{array}{l}\text { Perselingkuhan dan } \\
\text { Gratifikasi }\end{array}$ & $\begin{array}{l}\text { Pemberhentian tetap tidak } \\
\text { dengan hormat. }\end{array}$ \\
\hline
\end{tabular}

Sumber: Diolah dari data di Komisi Yudisial tahun 2009-2014

Dari tabel di atas terlihat bahwa selama periode 2009-2014 jumlah hakim yang dibawa ke Majelis Kehormatan Hakim (MKH) berjumlah 31 orang. Pelanggaran kategori berat para hakim itu menyangkut suap, perselingkuhan, pemalsuan putusan, narkoba, dan judi. Peningkatan cukup besar terjadi di 2014 
(sampai September), yaitu dari 7 orang pada 2013 menjadi 11 hakim pada 2014. Dari 11 hakim tersebut, 6 diantaranya diberhentikan dalam mekanisme MKH karena perselingkuhan.

Melalui pemeriksaan terhadap para terlapor, diperoleh data bahwa kelemahan integritas menyangkut kejujuran, kehati-hatian, kecermatan, kedisiplinan serta kemampuan ilmu pengetahuan dan teknis-teknis hukum dalam memeriksa, mengadili dan memutus perkara merupakan dasar penjatuhan sanksi.

Rekomendasi sanski ringan umumnya karena hakim sering terlambat sidang, mengantuk di ruang sidang, salah ketik dalam putusan, tidak mencantumkan daftar bukti yang seharusnya dituliskan lengkap dalam putusan. Sementara sanksi sedang kebanyakan antara lain: karena bertemu dengan pihak yang sedang berperkara, tidak menjaga prinsip imparsialitas atau berpihak dalam memeriksa, mengadili dan memutus perkata, meminjam uang dengan salah satu pihak, beristri kembali tanpa izin istri pertama. Sedangkan sanksi berat pada umumnya menerima suap dan atau selingkuh ${ }^{35}$.

Terkait selingkuh, KY belum ada data atau hasil penelitian tentang sebabsebab tingginya kasus perselingkuhan hakim, tetapi dari hasil pemeriksaan KY diperoleh informasi bahwa penyebabnya lebih karena rapuhnya integritas moral personality hakim-hakim bersangkutan. Disinilah urgensi keharusan seleksi integritas diperketat, melebihi seleksi kompetensi.

\section{Penutup}

Dari keseluruhan analisis di atas, dapat disimpulkan bahwa dari 2005 hingga 2011 laporan terus meningkat rata-rata 35 - 40\%setiap tahun. Bahkan peningkatan dari 2012 ke 2013 mencapai 50\%. Penyebab kecenderungan peningkatan laporan tersebut belum bisa dibaca secara detail, tetapi alasan umum kebanyakan pelapor adalah tidak percaya dengan proses pengadilan dan putusan

35 Terkait selingkuh, KY belum ada data atau hasil penelitian tentang sebab-sebab tingginya kasus perselingkuhan hakim, tetapi dari hasil pemeriksaan KY diperoleh informasi bahwa penyebabnya lebih karena rapuhnya integritas moral personality hakim-hakim bersangkutan. Disinilah urgensi keharusan seleksi integritas diperketat, melebihi seleksi kompetensi. 
hakim. Sementara kecenderungan asal wilayah laporan, pengadilan dari daerah Khusus Ibu Kota Jakarta, Jawa Timur Sumatera Utara, Jawa Barat, Jawa Tengah, Sulawesi Selatan, Riau, Sumatera Selatan, Nusa Tenggara Timur dan Banten merupakan wilayah sepuluh besar pengadilan pemasok laporan.

Sedangkan dari segi jenis persidangan yang mendominasi laporan; persidangan pidana, perdata dan TUN mendominasi laporan. Untuk jenis pelanggaran KE PPH; tindakan hakim yang tidak profesional, tidak berdisiplin tinggi, tidak adil, tidak jujur, dan tidak berintegritas tinggi adalah jenis pelanggaran dominan dari 10 poin KE PPH. Pada aspek jenis sanski, sanksi ringan mendominasi rekomendasi yang disampaikan ke MA.

Dari data-data yang terungkap, dapat diidentifikasi bahwa lemahnya integritas (kedisiplinan, kejujuran, dan kehati-hatian) serta kompetensi hakim (kemampuan ilmu pengetahuan, kecakapan di bidang hukum praktis) menjadi faktor utama dilanggarnya hukum acara serta Kode Etik dan Pedoman Perilaku sebagai salah satu elemen dari pengadilan yang fair. Karena itu, perubahan seleksi hakim menuju pengetatan seleksi unsur integritas dan kompetensi menjadi pilihan utama; di samping meningkatkan intensitas pembinaan dan pengawasan.

\section{Daftar Pustaka}

As'ad, Abd Rasyid, "Prinsip Kekuasaan Kehakiman dan Independensi Peradilan", Varia Peradilan, No.312 November 2011.

Ali, Achmad, Menguak Realitas Hukum: Rampai Kolom dan Artikel Pilihan Dalam Bidang Hukum, Kencana, Jakarta, 2008.

Abraham, Henry J. The Judicial Process, Oxford University Press, New York, 1993.

Berten, K. Etika, Gramedia Pustaka Utama, Jakarta, 2005.

Cardozo, Benjamin N., The Nature of The Judicial Process, New Haven: Yale University Press, 1921

Johansyah, J., “Independensi Hakim di Tengah Benturan Politik dan Kekuasaan”, dalam Reformasi Peradilan dan Tanggung Jawab Negara. Komisi Yudisial, Jakarta, 2010.

Komisi Yudisial RI, Dialektika Pembaharuan Sistem Hukum Indonesia, Komisi Yudisial, 2012.

Lubis, Suhrawardi K, Etika Profesi Hukum, Sinar Grafika, Jakarta, 2000. 
Raban, Offer, Modern Legal Theory and Judicial Impartiality, Publisher: RoutledgeCavendish, 2003.

Syamsudin, M., Konstruksi Baru Budaya Hukum Hakim Berbasis Hukum Progresif, Kencana Prenada Media Group, Jakarta, 2012.

Sihombing, Uli Parulian (Ed), Hak Atas Peradilan Yang Adil Yurisprudensi Pengadilan HAM Eropa, Komite HAM PBB dan Pengadilan HAM Inter Amerika, ILRC, Jakarta, 2008.

Suyuthi, Wildan, Kode Etik, Etika Profesi dan Tanggung Jawab Hakim, Pusdiklat MARI: Jakarta, 2004.

Sujata, Antonius, Hati Nurani Hakim dan Putusannya, PT Citra Aditya Bakti, Jakarta, 2007.

Simarmata, Rikardo (Ed) Indeks Persepsi Negara Hukum Indonesia 2012, ILR, Jakarta, 2013.

Judicial Indepencdence In Transitional Countries". UNDP Democratic Governance Fellowship Programme, 2003.

The Bangalore Principles of Judicial Conduct

Basic Principles On Independenceof The Judiciary

The Bangalore Principle of Judicial Conduct, 2001.

Basic Principles on the Independence of the Judiciary: 1985.

Beijing Statement Of Principles Of The Independence The Law Asia Region Of The Judiciary.

Kode Etik dan Pedoman Perilaku Hakim 